\title{
Immunoglobulin $\mathbf{G}$ and immunoglobulin $\mathbf{M}$ anti-Helicobacter pylori antibodies-diagnostic and prognostic value in gastritis
}

\author{
Lt Col Nikhil Moorchung*, Lt Pushkar Mendiratta ${ }^{\dagger}$, Brig Vibha Dutta, SM ${ }^{\#}$
}

MJAFI 2012;68:156-158

Key Words: antibody titres; gastritis; H. pylori

\section{INTRODUCTION}

Helicobacter pylori is a gram-negative, curved bacillus thought to play role in the pathogenesis of certain gastroduodenal diseases like non-ulcer dyspepsia (NUD), chronic inflammation, ulcers, etc. The $H$. pylori bacteria reside in the mucous layer covering the gastric epithelium, and therefore the type of protective measures that could confer resistance appear to be limited. Although, H. pylori infection stimulates strong local and systemic specific immunoglobulin (Ig) A and IgG antibody production, the influence of antibodies on bacterial colonisation and gastric inflammation is still debatable. ${ }^{1}$

\section{MATERIALS AND METHOD}

We investigated 30 patients of NUD. Informed consent was taken and antral biopsies were performed using standard upper gastrointestinal endoscopes (Olympus Optical Co Ltd., Tokyo, Japan). Three biopsies were taken and processed by standard methods. Biopsies were evaluated using a modification of the Sydney system. ${ }^{2}$ About $4 \mathrm{~mL}$ of peripheral blood was collected from the patients and the serum was separated. Serum samples stored at $-20^{\circ} \mathrm{C}$ were tested for the presence of IgG and IgM antibodies against $H$. pylori using standard enzyme-linked immunosorbent assay (ELISA) (Genesis diagnostics, UK). Eight controls were run with each set of samples. In addition to the positive and negative control, six serial dilutions of the antigen were included. A standard curve was constructed based upon the optical density (OD) of the controls. The OD of the test samples were then read off the curve. Repeat ELISA's were done as and when required.

\footnotetext{
*Associate Professor, "Professor and Head, Department of Pathology, ${ }^{\dagger}$ Ex-Medical Cadet, AFMC, Pune - 40.
}

Correspondence: Lt Col Nikhil Moorchung, Associate Professor, Department of Pathology, AFMC, Pune - 40. E-mail: nikhilmoorchung@rediffmail.com

Received: 23.09.2011; Accepted: 05.01.2012

doi: $10.1016 /$ S0377-1237(12)60038-0
The morphological parameters against which the IgG and IgM anti- $H$. pylori levels were measured were the density of various inflammatory cells like neutrophils, eosinophils, lymphocytes, and plasma cells. The IgG and IgM antibody titres were also compared with the grade of atrophy, the presence or absence of intestinal metaplasia, and glandular shortening. Lastly and most importantly, the titres were also compared with the presence and density of $H$. pylori.

\section{RESULTS}

Thirty patients were evaluated. The minimum IgG titre recorded was 0.111 and the maximum titre was $2.118 \mathrm{IU} / \mathrm{L}$. The mean IgG titre was $0.846 \mathrm{IU} / \mathrm{L}$ and the median titre was $0.655 \mathrm{IU} / \mathrm{L}$. The minimal IgM titre recorded was $0.424 \mathrm{IU} / \mathrm{L}$ and the maximum titre was $2.437 \mathrm{IU} / \mathrm{L}$. The mean titre was $1.046 \mathrm{IU} / \mathrm{L}$ and the median titre was $0.837 \mathrm{IU} / \mathrm{L}$.

No correlation between the various inflammatory parameters and the IgG and IgM antibody titres and no correlation between the antibody titres and the presence and grade of atrophy, gland shortening, and intestinal metaplasia was observed. In conclusion, we noted that there was no correlation between the antibody titres and the presence and density of $H$. pylori in the antral biopsies. Table 1 shows the $P$ value between the antibody titres and the various parameters.

\section{DISCUSSION}

This small pilot study did not find any correlation between the IgG and IgM titres and the severity of gastritis as assessed by histopathology. A few studies have found that there is a significant correlation between the severity of gastritis and the antibody titres. ${ }^{3}$ Yamamoto et al found that serum antiH. pylori IgG antibody titres were correlated significantly with the severity of inflammation in both the antrum and body. Significant associations were found between serum antiH. pylori IgG and IgA antibody titres and the development of atrophic gastritis. They did not find a correlation with antiH. pylori IgM titres. They concluded that their results suggest that measurement of serum anti-H. pylori antibody titres is 
Table 1 The correlation between the various inflammatory parameters and the IgG and IgM titres.

\begin{tabular}{|c|c|c|c|c|c|c|c|c|c|c|c|}
\hline IgG & $\lg M$ & Neutrophils & Lymphocytes & $\begin{array}{l}\text { Gland } \\
\text { atrophy }\end{array}$ & $\begin{array}{l}\text { Intestinal } \\
\text { metaplasia }\end{array}$ & Fibrosis & $\begin{array}{l}\text { Plasma } \\
\text { cells }\end{array}$ & Eosinophils & $\begin{array}{l}\text { Lymphoid } \\
\text { follicles }\end{array}$ & Activity & H. pylori \\
\hline 0.716 & 1.007 & 0 & 1 & 0 & 0 & 0 & 1 & 0 & 0 & 0 & 0 \\
\hline 1.631 & 0.6 & 1 & 2 & 0 & 0 & 1 & 2 & 0 & 2 & 0 & 1 \\
\hline 1.461 & 2.353 & 0 & 1 & 1 & 0 & 1 & 1 & 0 & 0 & 0 & 0 \\
\hline 0.417 & 1.329 & 0 & 1 & 1 & 0 & 1 & 1 & 0 & 3 & 0 & 0 \\
\hline 0.118 & 0.883 & 1 & 1 & 1 & 0 & 1 & 1 & 0 & 0 & 0 & 2 \\
\hline 0.586 & 1.773 & 0 & 2 & 1 & 0 & 1 & 2 & 0 & 2 & 1 & 0 \\
\hline 0.312 & 0.563 & 0 & 2 & 1 & 0 & 2 & 2 & 0 & 0 & 0 & 0 \\
\hline 1.371 & 1.001 & 0 & 2 & 1 & 0 & 1 & 2 & 0 & 0 & 0 & 0 \\
\hline 2.118 & 0.653 & 0 & 3 & 1 & 0 & 2 & 2 & 0 & 0 & 0 & 0 \\
\hline 0.881 & 2.237 & 1 & 3 & 1 & 0 & 1 & 2 & 0 & 0 & 0 & 2 \\
\hline 0.143 & 0.424 & 1 & 3 & 1 & 0 & 1 & 3 & 0 & 2 & 1 & 2 \\
\hline 0.118 & 0.883 & 1 & 1 & 2 & 0 & 2 & 1 & 0 & 3 & 0 & 2 \\
\hline 0.691 & 1.201 & 0 & 2 & 2 & 0 & 2 & 2 & 0 & 0 & 0 & 0 \\
\hline 1.811 & 0.54 & 1 & 2 & 2 & 0 & 2 & 2 & 0 & 0 & 1 & 2 \\
\hline 0.011 & 2.437 & 0 & 3 & 2 & 0 & 2 & 2 & 0 & 3 & 0 & 0 \\
\hline 1.238 & 0.757 & 1 & 3 & 2 & 0 & 2 & 3 & 0 & 2 & 0 & 1 \\
\hline 0.655 & 0.791 & 1 & 1 & 3 & 0 & 3 & 1 & 0 & 0 & 0 & 0 \\
\hline 0.37 & 1.008 & 2 & 2 & 3 & 0 & 2 & 2 & 1 & 2 & 1 & 2 \\
\hline 0.398 & 0.622 & 3 & 2 & 3 & 0 & 2 & 2 & 0 & 0 & 1 & 3 \\
\hline 0.533 & 0.637 & 0 & 3 & 3 & 0 & 3 & 2 & 0 & 0 & 0 & 0 \\
\hline 1.569 & 0.683 & 2 & 2 & 3 & 0 & 3 & 3 & 0 & 2 & 1 & 2 \\
\hline 0.155 & 1.231 & 0 & 3 & 3 & 0 & 3 & 3 & 0 & 0 & 0 & 0 \\
\hline 1.642 & 0.738 & 1 & 3 & 1 & 1 & 2 & 2 & 0 & 0 & 0 & 0 \\
\hline 1.953 & 0.519 & 1 & 3 & 2 & 1 & 2 & 2 & 1 & 2 & 0 & 1 \\
\hline 1.739 & 0.701 & 1 & 3 & 1 & 2 & 1 & 3 & 0 & 0 & 0 & 1 \\
\hline 0.404 & 1.134 & 2 & 3 & 2 & 2 & 2 & 3 & 0 & 2 & 0 & 2 \\
\hline 0.863 & 1.394 & 2 & 3 & 2 & 2 & 2 & 3 & 0 & 0 & 1 & 3 \\
\hline 0.2 & 1.65 & 1 & 2 & 3 & 2 & 3 & 2 & 0 & 2 & 1 & 2 \\
\hline 0.438 & 0.566 & 2 & 2 & 0 & 3 & 1 & 1 & 0 & 0 & 1 & 2 \\
\hline $\begin{array}{r}\text { IgG } \\
\text { inflam } \\
\text { para } \\
(P \mathrm{v}\end{array}$ & $\begin{array}{l}\text { and } \\
\text { natory } \\
\text { eters } \\
\text { ues) }\end{array}$ & 0.853 & 0.248 & 0.237 & 0.917 & 0.670 & 0.377 & 0.487 & 0.214 & 0.454 & 0.426 \\
\hline $\begin{array}{r}\text { IgM } \\
\text { inflam } \\
\text { parar } \\
(P \text { va }\end{array}$ & $\begin{array}{l}\text { and } \\
\text { natory } \\
\text { eters } \\
\text { ues) }\end{array}$ & 0.106 & 0.759 & 0.998 & 0.740 & 0.456 & 0.469 & 0.478 & 0.835 & 0.601 & 0.388 \\
\hline
\end{tabular}

useful in the diagnosis of $H$. pylori infection and severity of gastritis.

Other studies deny such a correlation. Gerencser et al concluded that serology does not always parallel the macroscopic pictures revealed by gastroscopy. ${ }^{4}$ However, the authors also felt that serology could play an important role in follow-up tests and examinations as well as in understanding the aetiology of different gastroduodenal diseases.

On the basis of a survey and of previous studies performed by them, Czinn et al concluded that at a serum dilution of 1:800, IgG but not IgA or IgM antibody to $H$. pylori is useful in the rapid screening of symptomatic children for the presence of H. pylori. ${ }^{5}$ This is an observation that has been contested by Akhiani who suggested that antibodies are not only dispensable for protection, but they impair both the elimination of bacteria and the development of gastritis. ${ }^{1}$ This effect appears to be IgA-dependent and is not a function of specific IgM or IgG antibodies. Therefore, the contention that IgA antibodies are irrelevant in the pathogenesis remains in doubt. IgA antibodies were not measured in the present study. However, our results show a lack of correlation between histopathology and IgG antibody titres as opposed to Czinn et al. ${ }^{5}$ 
In conclusion, this small pilot study failed to show a reasonable correlation between anti-H. pylori IgG and IgM titres and the severity of gastritis. Antibody titres do not appear to have a diagnostic and prognostic value. Histopathology remains the gold standard for the diagnosis of the disease.

\section{REFERENCES}

1. Akhiani AA. The role of type-specific antibodies in colonization and infection by Helicobacter pylori. Curr Opin Infect Dis 2005;18:223-227.
2. Moorchung N, Srivastava AN, Gupta NK, Achyut BR, Mittal B. The histopathology of chronic gastritis. Indian J Pathol Microbiol 2007;50:18-24.

3. Yamamoto I, Fukuda $\mathrm{Y}$, Mizuta $\mathrm{T}$, Fukada $\mathrm{M}$, Nishigami $\mathrm{T}$, Shimoyama T. Serum anti-Helicobacter pylori antibodies and gastritis. J Clin Gastroenterol 1995;21(Suppl 1):164-168.

4. Gerencser Z, Juhasz P, Nemasanszky E. Clinical significance of serological markers of Helicobacter pylori. Orv Hetil 1992;133:1877-1881.

5. Czinn SJ, Carr HS, Speck WT. Diagnosis of gastritis caused by Helicobacter pylori in children by means of an ELISA. Rev Infect Dis 1991;13(Suppl 8):S700-S703.

\section{Scientific Article for Awards}

\section{From the office of DGAFMS/DG-3B}

1. Scientific articles are invited from serving Medical/Dental officers of the Army, Navy, and Air Force for the following awards:

a. Chief of Army Staff Award for best published article in the field of pathology, microbiology, haematology, and biochemistry.

b. Chief of Naval Staff Award for best published article in the field of medicine and allied specialties including marine medicine and aviation medicine.

c. Chief of Air Staff Award for best published article in the field of surgery and allied specialties including dental surgery.

d. DGAFMS \& Sr Col Cmdt Award for best published article in the field of preventive and social medicine including epidemiology, biostatistics, health and hospital administration.

e. Late Lt Gen RS Hoon, PVSM, AVSM, Award (cardiac Sciences) carried out in Cardiology in the field of Medicine and Surgery and allied specialities.

2. Article should be submitted through proper channels as per the instructions to the authors printed in January 2012 issue of MJAFI. Ten copies each of the article should reach this office by 31 August 2012. Article received after due date and not through proper channel will not be considered for award.

3. The awards will be presented in the 61st Armed Forces Medical Conference at AFMC Pune in February 2013.

4. Officers will be entitled to submit only one article for consideration of each award. A board of officers at the office of the DGAFMS will evaluate the articles for selection of the best papers(s). The recipient(s) of the award will be given an opportunity, subject to exigencies of service to present his/her work at the time of presentation of the award.

5. Officers working in office of the DGAFMS are not eligible to compete for the awards.

Articles submitted by the officers other than those working in office of the DGAFMS but having co-authors working in the office of the DGAFMS will, however, be eligible for consideration of the award. However, the officers will not be eligible for any award/certificate or share of the prize money.

6. Validity of paper: Paper should have been published in the previous year i.e. award being presented in February 2013 would be for the year 2012 and so the article should have been published in between January 2011 and the date for submission.

7. Definition of author: The first or second author only be defined as author.

(Authority: Office of the DGAFMS/DG-3B, letter No 17090/Policy/28 (2002) DGAFMS/DG-3B dated 19 April 2002 and 17090/policy/ 2013/17/DGAFMS/DG-3B dated 12 March 2012) 